\title{
ETHYL ALCOHOL AS A FUEL FOR CONTEMPORARY INTERNAL COMBUSTION ENGINES
}

\author{
Miłosław KOZAK \\ Institute of Combustion Engines and Transport at Poznan University of Technology, ul. Piotrowo 3, \\ 60-965 Poznań, email: miloslaw.kozak@ put.poznan.pl
}

\begin{abstract}
The article presents the conditions for the use of ethyl alcohol as a component and a sole fuel for internal combustion engines. Methods of ethanol production, its properties and the benefits and risks associated with using it as engine fuel have been described. The variants of commercial ethanol fuels allowed by law have also been presented. Ecological aspects of the use of ethanol fuels for modern internal combustion engines were presented. The opinion was expressed that although ethanol is used in bulk as a component of gasolines, its use as a self-contained fuel is and probably will continue to be small in the near future.
\end{abstract}

Keywords: ethyl alcohol, combustion engines, motor fuels

\author{
ALKOHOL ETYLOWY JAKO PALIWO DO \\ WSPÓŁCZESNYCH SILNIKÓW SPALINOWYCH
}

\begin{abstract}
Streszczenie
W artykule przedstawiono uwarunkowania stosowania alkoholu etylowego jako składnika oraz samodzielnego paliwa do silników spalinowych. Opisano metody produkcji etanolu, jego właściwości oraz korzyści i zagrożenia związane ze stosowaniem go jako paliwa silnikowego. Zaprezentowano dopuszczalne prawem warianty handlowych paliw etanolowych. Przedstawiono ekologiczne aspekty stosowania paliw etanolowych do współczesnych silników spalinowych. Wyrażono opinię, iż mimo, że etanol stosowany jest masowo jako komponent benzyn silnikowych, to jego zastosowanie jako samodzielnego paliwa jest $\mathrm{i}$ prawdopodobnie w najbliższej przyszłości będzie niewielkie.
\end{abstract}

Słowa kluczowe: alkohol etylowy, silniki spalinowe, paliwa silnikowe

\section{INTRODUCTION}

The concept of using ethanol as a motor fuel appeared as early as at the beginning of the automotive development. Henry Ford built his first vehicles and fuelled them with ethanol in the eighties of the nineteenth century. Early Ford T models had a carburetor that could be adjusted for either gasoline or ethanol. In the interwar period and during World War II pure ethyl alcohol was occasionally used to power spark ignition engines. In 1928 started first ethanol based Polish fuel production which was blend of $30 \%$ ethanol and $70 \%$ gasoline [2]. Alcohols were used as components of fuel mixtures: gasoline-alcohol and gasoline-alcohol-benzene for many years after the war. In these mixtures, alcohol served primarily as a component increasing the fuel octane number, and its role as an energy carrier was secondary. In the nineties of the twentieth century, an additive of $5 \%$ ethanol for motor gasolines began to be used in Poland. The main purpose of using ethanol was to reduce the content of tetraethyl lead which was used at the time to increase the octane number of gasolines. However, some favorable changes in the composition of exhaust gases caused by the addition of ethanol were also noted, namely the reduction of $\mathrm{CO}$ emission by about $20 \%$ in the ECE cycle [4].

Currently, when fuel injection systems and catalytic aftertreatment systems are commonly used in spark-ignition (SI) engines, the importance of ethanol as a gasoline additive that reduces exhaust toxicity has decreased. Ethanol still plays an important role as a mean to increase the octane number of gasolines, especially due to restrictions on the content of aromatic hydrocarbons in fuel. It is used in its pure form and serves as a substrate for the production of high octane ethyl-tert-butyl ether (ETBE). However, the most important reason for the growing use of ethanol as an engine fuel today is the fact that it can be mass produced from biomass (bioethanol), i.e. as an environmentally friendly renewable fuel [7]. Ethyl alcohol can also be produced on industrial scale from ethylene, methanol or from synthesis gas $[8,19]$. However, taking into account the previously mentioned environmental aspects, and partly also social, economic and political factors, the most beneficial is the production of ethanol through biomass fermentation. 


\section{ETHYL ALCOHOL PRODUCTION}

Industrial production of ethanol by fermentation is a multi-stage process and includes: initial raw material preparation, hydrolysis and saccharification, detoxification (in the case of lignocellulosic biomass), fermentation, distillation and rectification, ethanol dehydration/drying, as well as the management of by-products and waste (Figure 1).

The enzymes produced by yeast in the process of alcoholic fermentation facilitate the decomposition of carbohydrates into ethyl alcohol and carbon dioxide. For example, the alcoholic fermentation of glucose proceeds according to the reaction:

$$
\mathrm{C}_{6} \mathrm{H}_{12} \mathrm{O}_{6} \rightarrow 2 \mathrm{C}_{2} \mathrm{H}_{5} \mathrm{OH}+2 \mathrm{CO}_{2} \text {. }
$$

A mash with alcohol concentration of up to $18 \%$ is obtained in the fermentation process (the yeast perishes at higher concentration). The concentration of alcohol is modified by distillation, the product of which is $90 \%$ ethanol is referred to as raw spirit, which is then rectified to obtain an azeotropic mixture of water and ethanol, with about $96 \%$ ethanol concentration. Ethanol used as a fuel component should not contain more than $0.3 \%$ of water, however, due to the formation of an azeotropic mixture, it is not possible to obtain anhydrous alcohol by conventional distillation. Removal of water from the azeotropic mixture is carried out using adsorption methods on molecular sieves and by pervaporation. The water content in dehydrated ethanol is 50 to $2000 \mathrm{ppm}$, depending on the process conditions.

In domestic conditions, ethanol is the most often produced from grains and potatoes. In the USA, Canada and China, the primary raw material is corn. The largest amount of ethanol production in the world (about 60\%) comes, however, from the processing of sugar cane. This raw material is used for example in Brazil. Raw materials for the production of bioethanol can generally be divided into three groups [1]:

- containing sucrose: sugar cane, beetroots and sugar sorghum and certain fruits,

- containing starch: wheat, rye, barley, potatoes, maize, rice, cassava,

- lignocellulosic biomass: energy crops, byproducts from agriculture and the wood industry, paper and cardboard being a fraction of municipal waste.
Bioethanol from the raw materials of the last group is a 2nd generation biofuel.

\section{PROPERTIES OF ETHANOL AS FUEL}

The physicochemical properties of ethanol (Table 1), in particular the high octane number, low viscosity and low boiling point, predispose it primarily as fuel for SI engines. The use of ethanol as a fuel brings both benefits and risks (Table 2), the latter being largely related to its impact on some construction materials of vehicles not adapted to be powered by ethanol. It is assumed that the maximum safe ethanol content in gasoline intended for conventional automotive SI engines is $10-15 \%$. The latest edition of the Worldwide Fuel Charter (2013) [20] recommends not exceeding the level of $10 \%$. Fuels with higher ethanol content can be used for the so-called FFV (Flexible Fuel Vehicles), i.e. vehicles that are factory-adapted for the use of this type of fuel. These vehicles are equipped with a fuel composition sensor and can be fuelled with an ethanol-gasoline mixture with any range of changes between the content of these two components. Several European car manufacturers offer FFV versions of their passenger cars (Table 3 ).

Table 1. Properties of ethanol as engine fuel [5]

\begin{tabular}{|c|c|c|c|}
\hline \multicolumn{2}{|l|}{ Parameter } & \multirow{2}{*}{$\begin{array}{c}\text { Ethanol } \\
789\end{array}$} & \multirow{2}{*}{$\begin{array}{c}\text { Gasoline } \\
\mathbf{9 5}\end{array}$} \\
\hline Density at $20^{\circ} \mathrm{C}$ & $\mathrm{kg} / \mathrm{m}^{3}$ & & \\
\hline $\begin{array}{l}\text { Research } \\
\text { octane number }\end{array}$ & - & 109 & $>95$ \\
\hline $\begin{array}{l}\text { Motor octane } \\
\text { number }\end{array}$ & - & 90 & $>85$ \\
\hline $\begin{array}{l}\text { Heat of } \\
\text { evaporation }\end{array}$ & $\mathrm{kJ} / \mathrm{kg}$ & 841 & 330 \\
\hline \multirow{2}{*}{ Heating value } & \multirow{2}{*}{$\begin{array}{c}\mathrm{MJ} / \mathrm{kg} \\
\mathrm{MJ} / \mathrm{dm}^{3}\end{array}$} & 26.8 & 43.5 \\
\hline & & 21.2 & 31.8 \\
\hline $\begin{array}{l}\text { Stoichiometric } \\
\text { air-fuel mixture }\end{array}$ & $\mathrm{kg}_{\text {air }} / \mathrm{kg}_{\text {fuel }}$ & 9,0 & 14,3 \\
\hline Distillation & ${ }^{\circ} \mathrm{C}$ & 78 & $40-215$ \\
\hline Flash-point & ${ }^{\circ} \mathrm{C}$ & 13 & -43 \\
\hline $\begin{array}{l}\text { Kinematic } \\
\text { viscosity at } 40^{\circ} \mathrm{C}\end{array}$ & $\mathrm{mm}^{2} / \mathrm{s}$ & 1.2 & 0.5 \\
\hline \multirow{4}{*}{$\begin{array}{l}\text { Elementary } \\
\text { composition } \\
\mathrm{C} \\
\mathrm{H} \\
\mathrm{O}\end{array}$} & \multirow[t]{4}{*}{$\% \mathrm{~m} / \mathrm{m}$} & & \\
\hline & & 52.2 & 84.8 \\
\hline & & 13.0 & 13.3 \\
\hline & & 34.8 & 2.4 \\
\hline
\end{tabular}

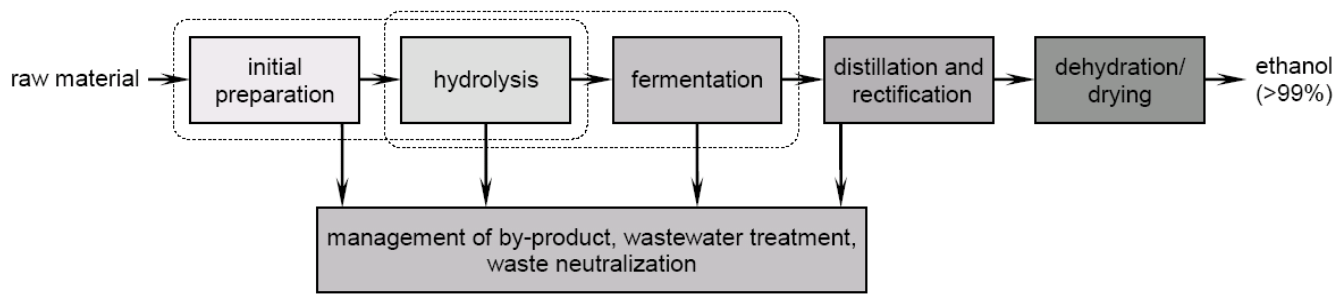

Fig. 1. Step by step processes and operations of ethanol production [6] 
Table. 2. Technical and operational advantages and risks associated with the use of ethanol as motor fuel [9]

\begin{tabular}{|c|c|}
\hline Advantages & Risks \\
\hline $\begin{array}{l}\text { - high octane number } \\
\text { allowing the increase } \\
\text { of compression ratio } \\
\rightarrow \text { engine efficiency } \\
\text { increase, } \\
\text { - CO, HC and PM } \\
\text { emissions reduced or } \\
\text { maintained at the } \\
\text { current level, } \\
\text { - reduction of CO } \\
\text { emissions (partial or } \\
\text { complete closure of } \\
\text { the CO cycle chain), } \\
\text { reduction of benzene } \\
\text { and other aromatics } \\
\text { emissions, } \\
\text { lower ozone } \\
\text { formation potential } \\
\text { than for pure } \\
\text { gasoline, } \\
\text { lower toxicity than } \\
\text { pure gasoline, } \\
\text { better flammability } \\
\text { than pure gasoline, } \\
\text { allowing the alcohol- } \\
\text { air mixtures to be } \\
\text { leaner, which may } \\
\text { result in a slightly } \\
\text { higher overall engine } \\
\text { efficiency, } \\
\text { higher flame propa- } \\
\text { gation speed (by } \\
\text { about 20-30\%), } \\
\text { which has the same } \\
\text { effect as above and } \\
\text { gives the possibility } \\
\text { of obtaining incre- } \\
\text { ased engine speed, } \\
\text { high heat of } \\
\text { evaporation } \\
\text { "internal" cooling of } \\
\text { the engine. }\end{array}$ & 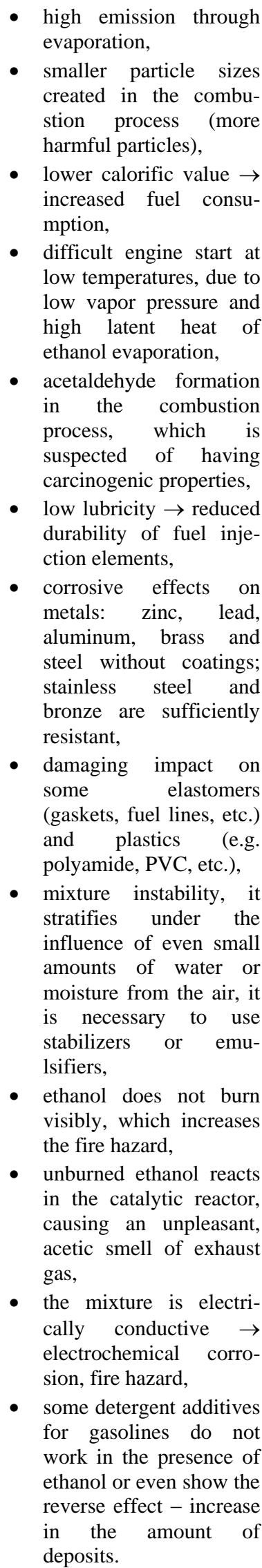 \\
\hline
\end{tabular}

Table. 3. Selected FFV models commercially available on the European market [11]

\begin{tabular}{|c|c|}
\hline FFV Vehicle Brand & Country \\
\hline $\begin{array}{l}\text { Audi A3 1.6e e-power (E85) } \\
\text { Audi A4 2.0 TFSI }\end{array}$ & Sweden \\
\hline $\begin{array}{l}\text { Citroën C3 Flex } \\
\text { Citroën C4 1.6/2.0 BioFlex } \\
\text { Citroën C5 2.0 BioFlex }\end{array}$ & $\begin{array}{l}\text { Sweden, Benelux, } \\
\text { France, Switzerland }\end{array}$ \\
\hline $\begin{array}{l}\text { Dacia Duster 1.6 16v (E85) } \\
\text { Dacia Logan MCV 1.6 16v Hi- } \\
\text { Flex (E85) } \\
\text { Dacia Sandero } 1.6 \text { 16v Hi-Flex } \\
\text { (E85) }\end{array}$ & Sweden \\
\hline $\begin{array}{l}\text { Ford Focus } \\
\text { Ford C-Max } \\
\text { Ford Mondeo } \\
\text { Ford S-Max } \\
\text { Ford Galaxy }\end{array}$ & $\begin{array}{c}\text { Austria, Denmark, } \\
\text { France, Germany, } \\
\text { Ireland, Holland, } \\
\text { Poland, Spain, } \\
\text { Sweden, } \\
\text { Switzerland, UK }\end{array}$ \\
\hline $\begin{array}{l}\text { Peugeot } 307 \text { 1.6/2.0 BioFlex } \\
\text { Peugeot } 308 \text { 1.6/2.0 BioFlex } \\
\text { Peugeot } 407 \text { 2.0 BioFlex }\end{array}$ & $\begin{array}{l}\text { Sweden, Benelux, } \\
\text { France, Switzerland }\end{array}$ \\
\hline $\begin{array}{l}\text { Renault Clio III 1.2 16v Eco2 } \\
\text { Renault Mégane } 1.6 \text { 16v Eco2 } \\
\text { Renault Kangoo 1.6 16v } 105\end{array}$ & $\begin{array}{l}\text { Sweden, Benelux, } \\
\text { France, Switzerland }\end{array}$ \\
\hline $\begin{array}{l}\text { SEAT Leon MultiFuel 1.6 MPI } \\
\text { (E85) } \\
\text { SEAT Altea MultiFuel 1.6 MPI } \\
\text { (E85) } \\
\text { SEAT Altea XL MultiFuel } 1.6 \\
\text { MPI (E85) }\end{array}$ & European market \\
\hline $\begin{array}{l}\text { Škoda Octavia MultiFuel } 1.6 \\
\text { MPI (E85) }\end{array}$ & $\begin{array}{l}\text { Sweden, Benelux, } \\
\text { France, Switzerland }\end{array}$ \\
\hline $\begin{array}{l}\text { Volvo C30 } 1.8 \mathrm{~F} \\
\text { Volvo S40 } 1.8 \mathrm{~F} \\
\text { Volvo V50 } 1.8 \mathrm{~F} \\
\text { Volvo V70 } 2.0 \mathrm{~F} \\
\text { Volvo V70 } 2.5 \mathrm{FT} \\
\text { Volvo S80 2.0F } \\
\text { Volvo S80 2.5FT }\end{array}$ & European market \\
\hline $\begin{array}{l}\text { Volkswagen Golf and Golf Plus } \\
\text { Volkswagen Jetta }\end{array}$ & $\begin{array}{l}\text { Germany, Sweden, } \\
\text { Benelux and } \\
\text { Switzerland }\end{array}$ \\
\hline
\end{tabular}

Ethanol is also considered as fuel for future high-performance engines $[5,16]$. Its parameters, such as high octane number and a large evaporation heat, which contribute to the effective cooling of the cylinder fuel mixture, are particularly desirable in high-performance engines. An engine designed for ethanol fuel may have a higher compression ratio, thus significantly improving the overall efficiency under low and medium load, a similar effect relates to the accelerated ignition.

\section{VARIANTS OF USING ETHANOL AS FUEL IN POLAND}

In Poland, it is legally permissible to produce and sell ethanol fuel in three variants:

(a) as a biocomponent of gasoline in an amount up to $5 \%(\mathrm{v} / \mathrm{v})$

(b) as a biocomponent of gasoline in an amount up to $10 \%(\mathrm{v} / \mathrm{v})$, 
(c) as a fuel component of E85, which is a mixture of motor gasoline and ethanol, in which the ethanol content ranges from 70 to $85 \%(\mathrm{v} / \mathrm{v})$.

Gasolines containing up to $10 \%$ of ethanol are classified as conventional fuels. The quality requirements that apply to them are listed in the Regulation of the Minister of Economy of 9 October 2015 on quality requirements for liquid fuels. There is a separate regulation that regulates the quality of bioethanol used as a component of these fuels (Table 4). E85 fuel is classified as biofuel. The quality requirements that apply to it are described in the Regulation of the Minister of Energy of May 25, 2016 regarding quality requirements for liquid biofuels. In that regulation, E85 fuel is formally called "motor gasoline containing from $70 \%$ to $85 \%$ bioethanol, used in vehicles equipped with spark-ignition engines adapted to the combustion of this liquid biofuel". The ethanol used to produce the E85 fuel must meet the requirements set out in Table 4. Despite the legal possibilities neither E10 (with a $10 \%$ ethanol content) nor E85 fuel can be found commonly available at fuel stations in Poland.

Table 4. Quality requirements for bioethanol used as a fuel biocomponent $[12,13]$

\begin{tabular}{|c|c|c|c|}
\hline \multirow{2}{*}{ Properties } & \multirow{2}{*}{ Unit } & \multicolumn{2}{|c|}{ Range } \\
\hline & & minimum & maximum \\
\hline $\begin{array}{l}\text { The content of } \\
\text { ethanol and } \\
\text { higher saturated } \\
\text { alcohols }\end{array}$ & $\begin{array}{c}\% \\
(\mathrm{~m} / \mathrm{m})\end{array}$ & 98.7 & - \\
\hline $\begin{array}{l}\text { The content of } \\
\text { mono-saturated } \\
\text { alcohols } \\
(\mathrm{C} 3-\mathrm{C} 5)\end{array}$ & $\begin{array}{c}\% \\
(\mathrm{~m} / \mathrm{m})\end{array}$ & - & 2.0 \\
\hline Methanol content & $\begin{array}{c}\% \\
(\mathrm{~m} / \mathrm{m}) \\
\end{array}$ & - & 1.0 \\
\hline Water content & $\begin{array}{c}\% \\
(\mathrm{~m} / \mathrm{m})\end{array}$ & - & 0.300 \\
\hline $\begin{array}{l}\text { The content } \\
\text { of inorganic } \\
\text { chlorides }\end{array}$ & $\mathrm{mg} / \mathrm{kg}$ & - & 6.0 \\
\hline Copper content & $\mathrm{mg} / \mathrm{kg}$ & - & 0.100 \\
\hline $\begin{array}{l}\text { Total acidity } \\
\text { (expressed as } \\
\text { acetic acid } \\
\text { content) }\end{array}$ & $\begin{array}{c}\% \\
(\mathrm{~m} / \mathrm{m})\end{array}$ & - & 0.007 \\
\hline Appearance & & \multicolumn{2}{|c|}{ clear and transparent } \\
\hline $\begin{array}{l}\text { Phosphorus } \\
\text { content }\end{array}$ & $\mathrm{mg} / \mathrm{l}$ & - & 0.15 \\
\hline $\begin{array}{l}\text { The content of } \\
\text { dry residue after } \\
\text { evaporation }\end{array}$ & $\begin{array}{c}\mathrm{mg} / \\
100 \mathrm{ml}\end{array}$ & - & 10 \\
\hline Sulfur content & $\mathrm{mg} / \mathrm{kg}$ & - & 10.0 \\
\hline $\begin{array}{l}\text { Electric } \\
\text { conductivity }\end{array}$ & $\mu \mathrm{S} / \mathrm{cm}$ & - & 2.5 \\
\hline Sulphate content & $\mathrm{mg} / \mathrm{kg}$ & - & 4 \\
\hline
\end{tabular}


energy consumption is very similar when using both fuels, and $\mathrm{CO}_{2}$ emissions is even lower for E85 (Figure 3) due to the more favorable hydrogencarbon ratio in the ethanol molecule.

Extensive tests of FFVs' fuel consumption were carried out by the United States Environmental Protection Agency (EPA). The test results of these vehicles are the most comprehensive data available for the comparison of gasoline and E85 fuel efficiency. For the 2007 year, 24 different models from 5 manufacturers were designated FFVs. Within these 24 models, there were 76 different drivetrain/body-style variants tested for gasoline and E85 fuel economy. Table 6 presents these results. The mean fuel economy of E85 in city driving was $73.42 \%$ that of gasoline. In highway driving, the mean fuel economy was $73.4 \%$ that of gasoline. The EPA also produces a mean fuel economy by averaging city and highway fuel economy, with a $55 \%$ city $/ 45 \%$ highway weighting. By this measure, the ratio of E85 to gasoline fuel economy was also $73.4 \%$ [14].

As the ethanol content in fuel increases, the content of harmful aromatic hydrocarbons in fuel decreases. Hence, decreases also emissions of aromatics in exhaust gas. According to [15] the total aromatic hydrocarbon emission is several times lower for an E85 powered vehicle than for a gasoline-powered vehicle (table 5).

Ethanol in its pure form is used very rarely as fuel for compression-ignition (CI) engines. There is in principle only one manufacturer on the automotive market that offers ethanol-powered CI engines, namely Scania. These engines have a high compression ratio (28) and require a special ED95 fuel. It is a mixture of $95 \%$ ethanol and a $5 \%$ package of additives improving, among others the ability of the fuel to self-ignite and its lubricity. The high compression ratio alone does not ensure proper ignition of the ethanol [10]. Scania's ethanol-powered CI engines are mainly used in city buses. Although this solution has been present on the market for over 20 years, less than one thousand ED95 buses have been manufactured so far, mainly for the Swedish market. In Poland, several buses powered by ED95 were operated at MZK Słupsk. After a few years, the carrier withdrew from this solution, due to high operating costs among other reasons. As shown by the data published in [10], the EEV (Enhanced Environmental Friendly
Vehicle) class bus fuelled with ED95 fuel has admittedly exhaust emissions similar to the conventional EEV bus fuelled with diesel fuel but also about $7 \%$ higher energy consumption.

Table 5. Emissions of aromatic compounds over the FTP-75 cycle for vehicles fuelled with fuels containing ethanol [15]

\begin{tabular}{|c|c|c|c|c|}
\hline \multicolumn{5}{|c|}{ Nissan passenger car emissions [mg/km] } \\
\hline & Benzene & Toluene & Xylenes & $\begin{array}{c}\text { Total } \\
\text { aromatics }\end{array}$ \\
\hline Gasoline & 4.08 & 5.23 & 5.30 & 18.96 \\
\hline E10 & 4.35 & 4.75 & 5.21 & 19.43 \\
\hline E45 & 1.14 & 1.20 & 1.44 & 5.05 \\
\hline E85 & 0.31 & 0.31 & 0.53 & 1.68 \\
\hline \multicolumn{5}{|c|}{ GM pick-up emissions [mg/km] } \\
\hline & Benzene & Toluene & Xylenes & $\begin{array}{c}\text { Total } \\
\text { aromatics }\end{array}$ \\
\hline Gasoline & 1.40 & 3.45 & 3.34 & 11.00 \\
\hline E10 & 1.17 & 3.01 & 3.70 & 11.38 \\
\hline E45 & 0.51 & 1.40 & 0.99 & 4.08 \\
\hline E85 & 0.37 & 1.23 & 0.77 & 3.15 \\
\hline
\end{tabular}

\section{CONCLUSIONS}

Ethyl alcohol has been used for many years as a few percent additive to regular gasoline. Its valuable feature, both in the past and today, is increasing the octane number of fuel. In the era of using advanced catalytic exhaust aftertreatment systems, the effect of ethanol on toxic exhaust emissions is less important. At present, the main advantage of ethanol in the environmental aspect is the fact that it is a renewable fuel that leads to a reduction in $\mathrm{CO}_{2}$ emissions and lower dependence on fossil fuel resources. It is also definitely less toxic and more readily biodegradable than gasoline. Despite the legal and technical possibilities, in Poland and most other countries the market of vehicles powered with neat ethanol or mixtures with a high ethanol content is not developed. FFVs have a significant market share in only a few countries around the world. At the same time, work is being carried out on fuels for future engines, including HCCI engines, for which ethanol is also considered as potential fuel component. The production of ethanol is still mainly based on the use of raw materials from edible plants containing

Table 6. Summary statistics of EPA FFV fuel economy tests [14]

\begin{tabular}{|l|c|c|c|c|c|c|c|c|c|}
\hline & \multicolumn{3}{|c}{ City } & \multicolumn{3}{c|}{ Highway } & \multicolumn{3}{c|}{ Average } \\
\cline { 2 - 10 } & Gasoline & E85 & Ratio & Gasoline & E85 & Ratio & Gasoline & E85 & Ratio \\
\hline Mean & 14.9 & 10.9 & $73.4 \%$ & 19.8 & 14.6 & $73.4 \%$ & 17.1 & 12.6 & $73.4 \%$ \\
\hline Minimum & 13.1 & 9.1 & $66.9 \%$ & 16.7 & 12.4 & $67.6 \%$ & 14.7 & 10.8 & $68.3 \%$ \\
\hline Maximum & 21.8 & 15.8 & $81.3 \%$ & 31.2 & 23.4 & $81.5 \%$ & 25.8 & 19.2 & $81.4 \%$ \\
\hline
\end{tabular}

Notes: Nominal values are EPA estimated miles travelled per gallon consumed. 'Ratio' is the ratio of E85 fuel economy to gasoline fuel economy. 'Average' is the average of 'City' and 'Highway' weighted 55\% 'City' and 45\% 'Highway'. $\mathrm{N}=76$ total vehicles tested. 
sucrose or starch. The technologies of ethanol production from non-food raw materials, mainly from lignocellulosic complexes, developed for about last 20 years, have still not had a significant share in this fuel production market. Although ethanol remains a very important component of fuels for SI engines, the scale of its use as an independent motor fuel is growing slowly. It also seems that the coming years will not bring a significant change in this field.

\section{REFERENCES}

1. Balat $\mathrm{M}$, Balat $\mathrm{H}$. Recent trends in global production and utilization of bio-ethanol fuel. Applied Energy 2009; 86: 2273-2282.

https://doi.org/10.1016/j.apenergy.2009.03.015.

2. Bielaczyc P, Woodburn J, Gandyk M, Szczotka A. Ethanol as an automotive fuel - a review. Combustion 2016; 166(3): 39-45. https://doi.org/10.19206/CE-2016-338.

3. Dardiotis C, Fontaras G, Marotta A, Martini G, Manfredi U. Emissions of modern light duty ethanol flex-fuel vehicles over different operating and environmental conditions. Fuel 2015; 140: 531-540. doi: 10.1016/j.fuel.2014.09.085.

4. Jakóbiec J, Marchut A, Jaskólski J. Exhaust emissions of engines fuelled with gasoline with bioethanol. Journal of KONES 2000: 146-153. Polish.

5. Kałużny J. et al. An innovative system for piston engine combustion with laser-induced ignition of the hydrocarbon fuel consisting carbon nanotubes. Combustion Engines 2017; 168(1): 3-14, https://doi.org/10.19206/CE-2017-101.

6. Klimiuk E, Pawłowska M, Pokój T. Biofuels technologies for sustainable development. PWN Warszawa; 2012. Polish.

7. Leja K, Lewandowicz G, Grajek W. Production of bioethanol from cellulose raw materials. Biotechnologia, 2009; 4(87): 88-101. Polish.

8. Liu Y, Murata K, Inaba M, Takahara I. Synthesis of ethanol from methanol and syngas through an indirect route containing methanol dehydrogenation, DME carbonylation, and methyl acetate hydrogenolysis. Fuel Processing Technology 2013; 110: 206-213. https://doi.org/10.1016/j.fuproc.2012.12.016.

9. Merkisz J, Kozak M, Teodorczyk A. Benefits and risks associated with the use of biofuels in internal combustion engines. Archiwum Spalania, 2003, 3(1). Polish.

10. Nylund N, Koponen K. Fuel and Technology Alternatives for Buses. VTT Technical Research Centre of Finland; 2012.

11. Pałuchowska M, Stępień Z, Żak G. The prospects for the use of ethanol as a fuel component and its potential in the reduction of exhaust emissions. Combustion Engines 2014; 158(3): 80-92.

12. Regulation of the Minister of Economy of 14 May 2015 amending the regulation on quality requirements for biocomponents, methods for testing the quality of biocomponents and the method of sampling biocomponents. Polish. Dz.U. 2015 poz. 780 .
13. Regulation of the Polish Minister of Economy of 17 December 2010 on quality requirements for biocomponents, methods for testing the quality of biocomponents and the method of sampling biocomponents. Polish. Dz.U. 2010 nr 249 poz. 1668.

14. Roberts MC. E85 and fuel efficiency: An empirical analysis of 2007 EPA test data. Energy Policy 2008; 36: $1233-1235$.

https://doi.org/10.1016/j.enpol.2007.11.006.

15. Schifter I. et al. From actual ethanol contents in gasoline to mid-blends and E-85 in conventional technology vehicles. Emission control issues and consequences. Fuel 2018; 219: 239-247.

https://doi.org/10.1016/j.fuel.2018.01.118

16. Schwaderlapp M, Adomeit P, Kolbeck A, Thewes M. Ethanol and its potential for downsizing engine concepts. MTZ - Motortechnische Zeitschrift 2012; 73(2): 120-125. German.

https://doi.org/10.1365/s35146-012-0246-0.

17. Smith TW, Axon CJ, Darton RC. The impact on human health of car-related air pollution in the UK, 1995-2005. Atmospheric Environment 2013; 77: 260-266.

https://doi.org/10.1016/j.atmosenv.2013.05.016.

18. Suarez-Bertoa R, Zardini A, Keuken H, Astorga C. Impact of ethanol containing gasoline blends on emissions from a flex-fuel vehicle tested over the Worldwide Harmonized Light Duty Test Cycle (WLTC). Fuel 2015; 143: 173-182. https://doi.org/10.1016/i.fuel.2014.10.076.

19. Wender I, Friedel R, Orchin M. Ethanol from Methanol. Science 1951; 113: 206-207. https://doi.org/10.1126/science.113.2930.206.

20. Worldwide Fuel Charter 2013.

\section{Received 2019-01-08}

Accepted 2019-05-06

Available online 2019-05-07

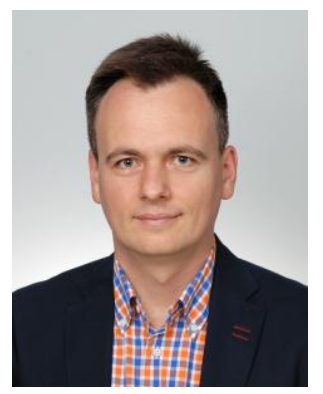

Miłosław Kozak, DSc, DEng, graduated with honors at the Faculty of Mechanical Engineering of the Lublin University of Technology in 1998, he obtained further academic degrees at the Faculty of Transport at the Poznan University of Technology. Main areas of his scientific activity include: conventional and alternative motor fuels, automotive pollution of the environment, on-board emission measurement systems (PEMS), environmental macro and microsimulation of road traffic and the use of thermogravimetric methods, chromatography and mass spectrometry in the study of ecological properties of means of transport. 